\title{
INVESTORS AT CONFLICT'S CROSSROADS: AN OVERVIEW OF AVAILABLE INTERNATIONAL COURTS AND TRIBUNALS IN THE CRIMEAN CONTEXT
}

\author{
Nataliia Tuzheliak*
}

\begin{abstract}
The annexation of the Crimean Peninsula, as well as the conflicts in Georgia and Cyprus, pose questions such as to what extent states can and should guarantee long-term investment protection in the contemporary dynamics of the international legal order. This article does not analyse the broader problems concerning territorial and diplomacy issues; rather, it centres on problems regarding economic interests and property rights protection. This article provides an overview and analysis of the international venues for protection of investors and investments from third states' conduct outside their borders. This article analyses the conflict in Crimea, a peninsula located in southern Ukraine. This case study is used as a backdrop for the examination of investment treaties' application (and applicability), as well as available protection mechanisms in international law in a context of disputed borders.
\end{abstract}

\section{A. INTRODUCTION}

Global political processes affect the development of the international legal order. It took centuries for societies to codify the principles of civil protection in times of armed conflict, including concepts like force majeure and hardships. ${ }^{1}$ The international investment law regime has traditionally viewed investors and investment protection as its centre of gravity and has attempted to balance the investor's interests with the state's legitimate right to regulate. ${ }^{2}$ If an external stream of great velocity disturbs this system, the balance is lost for the whole habitat.

The conflict over the Crimean Peninsula provides a backdrop for the analysis undertaken in this article. Geographically, Crimea is a peninsula located in the south of Ukraine, surrounded by the Black Sea and the Sea of Azov. Historically, the Crimean Peninsula was part of the Bosporus Kingdom, Byzantine and Ottoman empires. Catherine II

\footnotetext{
* International lawyer and advocate admitted to practice in Ukraine; Chevening Scholar of the Foreign \& Commonwealth Office; Queen Mother Scholar of The Honourable Society of the Middle Temple; LLM (Distinction) University College London; Visiting Foreign Lawyer with Sterling Lawyers Ltd in London. The author wishes to express her gratitude to Dr Martins Paparinskis for his devoted guidance provided during the research and completion of her dissertation on which this article is based. The author's heartfelt appreciation goes to Edouard Bertagna for his warm and sincere support as well as to Edita Maric, Natassa Choromidou, Eleni Stylianou, Preetika Mishra and Lucila Marchini for their help and advice. Special gratitude is extended to this journal's editors Luis Viveros, Nikolaos Pavlopoulos and Jessie Barnett-Cox for their valuable comments. Views and errors are solely author's responsibility.

${ }^{1}$ Geneva Convention Relative to the Protection of Civilian Persons in Time of War (adopted 12 August 1949, entered into force 21 October 1950) 75 UNTS 287 (Fourth Geneva Convention). See also Joern Rimke, 'Geneva Convention Relative to the Protection of International Trade Practice with Specific Regard to the CISG and the UNIDROIT Principles of International Commercial Contracts' (2001) 84 Pace Intl L Rev 197.

${ }^{2}$ Roland Kläger, Fair and Equitable Treatment' in International Investment Law (CUP 2011) 162.
} 
of Russia established a long-lasting protectorship over the peninsula in $1783 .^{3}$ The Union of Soviet Socialist Republics (Soviet Union) held it under its control from 1921, lost it briefly to Nazi Germany and reclaimed it at the end of World War II. In 1954, Crimea was acquired by the Ukrainian Soviet Socialist Republic and remained a part of Ukraine as an independent state since $1991 .^{4}$

After the 2014 civil disturbances and revolution in Ukraine, ${ }^{5}$ which resulted in a presidential election and the formation of a new government, Russian military troops started to assert control over the peninsula ${ }^{6}$ in violation of the Budapest Memorandum on Security Assurances. ${ }^{7}$ After the Russian military intervention and rebellious demonstrations in support of Crimea's independence, a referendum on the status of Crimea was held. ${ }^{8}$ Notwithstanding its unconstitutionality from the Ukrainian domestic perspective, ${ }^{9}$ the referendum results were ratified and followed by a declaration of sovereignty. ${ }^{10}$ Russia officially recognised that declaration ${ }^{11}$ and subsequently ratified the Agreement on Admission of the Republic of Crimea into the Russian Federation (Crimea Agreement), formally incorporating the Crimean territory into its federal structure. ${ }^{12}$

The international community's reaction to these events in the form of economic sanctions imposed against Russia ${ }^{13}$ resulted in countersanctions and expropriation of foreign

\footnotetext{
${ }^{3}$ Thomas Milner, The Crimea, its Ancient and Modern History (General Books 2012).

${ }^{4}$ Paul Kubicek, The History of Ukraine (Greenwood Press 2008).

5 'The February Revolution: Can Ukraine Find any Leaders Who Will Live up to the Aspirations of its Battered, Victorious but Skeptical Protesters?' The Economist (27 February 2014)

$<$ www.economist.com/news/briefing/21597974-can-ukraine-find-any-leaders-who-will-live-up-aspirations-itsbattered-victorious $>$ accessed 4 July 2017.

${ }^{6}$ William Booth and Karen DeYoung, 'Reports of Russian Military Activity in Crimea Prompts Stern Warning from Obama' The Washington Post (1 March 2014) <www.washingtonpost.com/world/ukraine-calls-russiantroops-invasion/2014/02/28/e066bfc8-a0be-11e3-878c-65222df220eb_story.html> accessed 16 August 2016.

${ }^{7}$ UNSC Res 1399 (19 December 1994) UN Doc S/RES/1399.

${ }^{8}$ Ian Birrell, 'Crimea's Referendum was a Sham Display of Democracy' The Guardian (17 March 2014) $<$ www.theguardian.com/commentisfree/2014/mar/17/crimea-referendum-sham-display-democracy-ukraine> accessed 27 August 2016.

${ }^{9}$ Constitution of Ukraine (adopted 28 June 1996, entered into force 13 July 1996) 30 Official Journal of the Verkhovna Rada of Ukraine 141 arts 135-37.

10 'Crimea's Parliament has Formally Declared Independence from Ukraine and Asked to Join the Russian Federation' BBC News (17 March 2014) <www.bbc.co.uk/news/world-europe-26609667> accessed 16 August 2016.

${ }^{11}$ Steven Myers and Peter Baker, 'Putin Recognizes Crimea Secession, Defying the West' The New York Times (17 March 2014) <www.nytimes.com/2014/03/18/world/europe/us-imposes-new-sanctions-on-russianofficials.html?hp\&_r=1> accessed 16 August 2016 .

${ }^{12}$ On Ratification of the Agreement between the Russian Federation and the Republic of Crimea on the Admission of the Republic of Crimea into the Russian Federation and on the Creation of New Constituent Entities within the Russian Federation see Federal Law of the Russian Federation No 36-FZ of 21 March 2014 (Crimea Agreement).

${ }^{13}$ UNGA 'Territorial Integrity of Ukraine' UNGA Res 68/262 (27 March 2014) UN Doc A/RES/68/262. See also Richard Happ and Sebastian Wuschka, 'Horror Vacui: or why Investment Treaties Should Apply to Illegally Annexed Territories' (2016) 33 (3) J Intl Arb 245; Gaiane Nuridzhanyan, 'Ukraine vs Russia in
} 
investment by Russia in Crimea. ${ }^{14}$ The process of establishing an administration over the territory - the so-called legal 'russianization' of Crimea - began in March 2014 with the nationalisation of property in late April $2014^{15}$ and nearly complete establishment of the Crimean Federal system of governance, a process which allegedly ended in late $2014 .^{16}$

This complex geopolitical situation falls in line with the peninsula's history. ${ }^{17}$ At the same time, that geopolitical and inter-state-centred analysis overlooks arrangements concerning the general protection of individuals heavily affected in their rights. These rights have different sources: customary international law dealing with inter-state matters; international human rights law conferring rights directly to individuals; and international foreign investment law dealing with individual and corporate foreign investors.

International law without adjudication has been the norm in international affairs. ${ }^{18}$ Many international legal frameworks have existed without a judicial enforcement mechanism attached to them. ${ }^{19}$ Moreover, states have historically gone out of their way to justify all sorts of illegal behaviour from the viewpoint of international law. ${ }^{20}$ The lack of effectiveness of traditional enforcement mechanisms gave rise to so-called judicialisation of international law. In turn, the proliferation of international courts and tribunals has caused fragmentation ${ }^{21}$ but, at the same time, increased the availability of different adjudicative settlement options. ${ }^{22}$

International Courts and Tribunals' EJIL:Talk! (9 March 2016) <www.ejiltalk.org/ukraine-versus-russia-ininternational-courts-and-tribunals/> accessed 30 April 2017.

${ }^{14}$ According to the United States Department of State: '...[i]n late March, Senator Andrei Klishas of the Federation Council, the upper chamber of Russia's national legislature, said the Council plans to draft legislation which would allow the confiscation of property, assets, and accounts of American and EU companies, including private companies, as a retaliatory measure on possible sanctions from the US and EU' in 'Executive Summary: 2014 Investment Climate Statement' US Department of State. Diplomacy in Action (15 June 2014) <www.state.gov/documents/organization/228199.pdf $>$ accessed 16 August 2016. See also Lyudmila Alexandrova, 'Crimean Roads may be Nationalised' TASS (25 March 2014) <www.tass.ru/en/russia/725137> accessed 18 July 2016.

${ }^{15}$ On the Matters of Property Management of the Republic of Crimea, Decree of the Council of State of the Republic of Crimea No 2085-6/14 of 30 April 2014 (as amended on 3 September 2014). This decree concerns transfer of property and its operational management to the Russian Federation for an indefinite period.

${ }^{16}$ Nikolai Petrov, 'Crimea: Transforming the Ukrainian Peninsula into a Russian Island' (2016) 54(1) Russian Politics \& L 74.

${ }^{17}$ Nuridzhanyan (n 13).

${ }^{18}$ Sir Robert Jennings compares judicial settlement to the 'extreme decision, non-pacific alternative of war', stressing that referring to the international court shall not be 'an act of routine' as in municipal law, in Laurence Boisson de Chazournes, Marcelo G Kohen and Jorge Viñuales, Diplomatic and Judicial Means of Dispute Settlement (Martinus Nijhoff Publishers 2012) 328.

${ }^{19}$ Ian Cram, Terror and the War on Dissent: Freedom of Expression in the Age of Al-Qaeda (Springer Science \& Business Media 2009) 25.

${ }^{20}$ Judgment of the Nuremberg International Military Tribunal 1946 (1947) 41 AJIL 172.

${ }^{21}$ Cesare P R Romano, 'The Shadow Zones of International Judicialisation' in Cesare PR Romano, Karen J Alter and Chrisanthi Avgerou (eds), The Oxford Handbook of International Adjudication (OUP 2013) 128.

22 Philip C Jessup, 'The Reality of International Law' Foreign Affairs (1 January 1940) $<$ www.foreignaffairs.com/articles/1940-01-01/reality-international-law> accessed 24 August 2016. 
Focusing on the economic harm suffered as a result of the political clashes at the root of the conflict, this article analyses the judicial venues for protection of foreign investors in Crimea. It argues that, although foreign investors have multiple international judicial fora where their rights may be asserted, these venues are seriously limited. The overall conclusion is that these venues are a toolbox of valuable but limited options for investors in the midst of a challenging situation. The argument will be developed in three sections.

The first pillar of the argument deals with the direct protection of foreign investments and of foreign investors in Crimea through the investor-state arbitration framework. It portrays the essential idea that property and individuals are the objects of protection under the investment treaty regime. Following the establishment of the object of protection, it explores a variety of jurisdictional issues. The study analyses the fulfilment of material and personal components of the scope of protection in the investment treaty regime between Russia and Ukraine. The first issue regards the status of Crimea itself, which remains de jure territory of Ukraine and consequences of this status vis-à-vis companies incorporated in Ukraine and their foreign shareholders. The second issue concerns illegality of territorial acquisition and its interrelation with the principles on succession of treaties.

The second section analyses available venues of protection under human rights frameworks. Available avenues analysed regard individual applications and inter-state proceedings. It is suggested that regional human rights frameworks, particularly the European Convention of Human Rights (ECHR), allows for the extraterritorial application of certain obligations and thus the protection of individual rights. This article studies the possibility of applying personal and territorial models of jurisdiction for the purpose of ascertaining the applicability of investment treaties vis-à-vis Russia. It suggests that the effective control model would allow to ascertain that Russia may be legally liable vis-à-vis harmful actions that affected investors in Crimea. The nationality requirement present in investment law does not play a substantial role in the human rights treaty protection regime as it does in the investor-state treaty framework. In addition, an analysis regarding the limitations on the protection of shareholders' rights under this system is offered. Finally, the article analyses the exhaustion of domestic remedies requirement and the issue of reparations in the human rights context.

The third section elaborates on the diplomatic protection framework. This route, it is argued, offers an attractive possibility for investors whose home states do not have an investment framework with Russia. However, this regime has considerable limitations, including its discretionary and politically sensitive nature. 
This article does not aim to provide an exhaustive examination of all available judicial venues. There may be other possibilities. However, those analysed in this article are wellestablished functioning forums that, in any case, are limited in the concrete circumstances present in situations of unlawful acquisition of territories. The article also does not seek to provide analysis on the illegality of Russia's use of force in Crimea. It is generally accepted and is a premise of the article upon which this analysis is offered that Russia's annexation of Crimea is not consistent with international law on the matter. ${ }^{23}$ The purpose is rather different: showing how international law, for all its limitations, remains the ultimate source of protection for individuals and their rights in the midst of complex and overwhelming situations in the international political arena.

\section{B. THE INVESTOR-STATE ARBITRATION FRAMEWORK FOR THE PROTECTION OF FOREIGN INVESTORS IN CRIMEA}

\section{Conceptions of foreign investors and foreign investment}

The object of protection under the investment regime concerns both individuals and property. Historically, investors are regarded as individuals in the first place, whereas the protection of corporate bodies as investors has been almost completely ignored until recently. ${ }^{24}$

In general, the facilitation of foreign investment as the fundamental purpose of the regime presumes investors, both corporate and natural persons, to be 'foreign'. This creates a requirement of investors' nationality ${ }^{25}$ or permanent residency, ${ }^{26}$ in order for them to be subjects of rights. ${ }^{27}$ With a higher degree of complexity, the same rule applies to corporate investors. It requires, respectively, a legal entity to be incorporated under the law of a contracting state, ${ }^{28}$ or to have a corporate seat in a contracting state, ${ }^{29}$ to conduct substantial

\footnotetext{
${ }^{23}$ UNGA Res 68/262 (2014) (n 13) para 5.

${ }^{24}$ Martins Paparinskis, The International Minimum Standard and Fair and Equitable Treatment (OUP 2013) 217.

${ }^{25}$ Convention on the Settlement of Investment Disputes Between the States and Nationals of Other States (adopted 18 March 1965, entered into force 14 October 1966) 575 UNTS 159 (ICSID Convention) art 25(2)(a).

${ }^{26}$ North American Free Trade Agreement (adopted 12 December 1992, entered into force 1 January 1994) US Gov't Printing Office 1992 (NAFTA) art 201. See also Agreement between the Federal Republic of Germany and the Union of Soviet Socialist Republics Concerning the Promotion and Reciprocal Protection of Investments (signed 13 June 1989, entered into force 5 August 1991) ('Germany-Soviet Union BIT') art 1.

${ }^{27}$ Zachary Douglas, The International Law of Investment Claims (CUP 2009) para 602.

${ }^{28}$ Energy Charter Treaty (adopted 17 December 1991, entered into force 16 April 1998) 2080 UNTS 95 (ECT) art 1(7).

${ }^{29}$ Germany-Russia BIT, art 1(1)(c).
} 
business activities, owned and controlled by a natural or legal person of a contracting state's nationality or incorporation. ${ }^{30}$

With regards to property, the term 'investment' evolved from the flexible and pragmatic approach $^{31}$ of contribution, certain duration and acceptance of risk, ${ }^{32}$ into a more complex concept where it is the consent of the parties that shapes the meaning of investment in different treaty instruments. ${ }^{33}$ The parties to the treaty can define what type of asset ${ }^{34}$ or economic contribution constitutes an investment. ${ }^{35}$ The Tribunal in Romak SA v Uzbekistan concluded:

[I]rrespective of whether the investor resorts to ICSID or UNCITRAL arbitral proceedings, investment entails a contribution that extends over a certain period of time and involves some risk ... [I]f an asset does not correspond to the inherent definition of investment, the fact that it falls within one of the categories listed in [the BIT] ... does not transform it into investment. ${ }^{36}$

Put another way, the consent of the contracting parties constitutes and limits the meaning of investment. ${ }^{37}$ On this basis, tribunals consider a particular contribution or an economic activity in light of its inherent definition ${ }^{38}$ with reference to the applicable treaty wording. ${ }^{39}$

Investors, both natural and legal persons, therefore have different venues available for the protection of their rights. Foreign investment arbitration is available to both individuals and corporations, while international human rights protection focuses mainly on individuals. Diplomatic protection, in turn, is exercised by states on behalf of investors, be they natural or legal persons. Keeping this differentiation in mind, the article now turns to the analysis of the investment treaties' mechanism as a direct system of protection.

2. The pragmatic approach to the applicability of investment treaties in the territory of Crimea

\footnotetext{
${ }^{30}$ Tokios Tokelès v Ukraine, ICSID Case No ARB/02/18, Dissenting Opinion (Chairman Prosper Weil) of 29 April 2004.

${ }^{31}$ Biwater Gauff Limited v Tanzania, ICSID Case No ARB/05/22, Award of 24 July 2008 , para 316.

${ }^{32}$ Salini Costruttori SpA and Italstrade SpA v Morocco, ICSID Case No ARB/00/4, Decision on Jurisdiction of 23 July 2001.

${ }^{33}$ Malaysian Historical Salvors, SDN, BHD v Malaysia, ICSID Case No ARB/05/10, Award on Jurisdiction of 17 May 2007, para 48.

34 ECT, art 1(6).

${ }^{35}$ Romak $S A$ v Uzbekistan, UNCITRAL, PCA Case No AA280, Award of 26 November 2009, para 205.

36 ibid paras $180,207$.

37 NAFTA, art 1139.

${ }^{38}$ Abaclat and Others $v$ Argentina, ICSID Case No ARB/07/5, Decision on Jurisdiction and Admissibility of 28 October 2011, para 364.

${ }^{39}$ Douglas (n 27) para 604.
} 
a) Jurisdictional challenges for arbitral tribunals in current disputes concerning investments in Crimea

Ukraine has triggered proceedings at the International Court of Justice (ICJ) and the International Tribunal for the Law of the Sea (ITLOS) in relation to the Crimean conflict. These are not analysed in this article because they do not directly concern the protection of investment in Crimea, or only have ancillary implications in that regard. ${ }^{40}$

Eight investment arbitration proceedings have been launched following the annexation of Crimea, two of which are being brought by Ukrainian state-owned companies. ${ }^{41}$ Ukrainian investors have brought claims under the United Nations Commission on International Trade Law Arbitration Rules $1976^{42}$ (UNCITRAL Rules) pursuant to the bilateral Agreement between the Government of the Russian Federation and the Cabinet of Ministers of Ukraine on the Encouragement and Mutual Protection of Investments ${ }^{43}$ (RussiaUkraine BIT). As the matter stands at the time this article is being drafted, Russia ${ }^{44}$ does not recognise the jurisdiction of the arbitral tribunal. ${ }^{45}$ However, this did not preclude the arbitral tribunal from issuing its awards addressing certain issues of jurisdiction. ${ }^{46}$ Although the

\footnotetext{
${ }^{40}$ Case Concerning the Application of the International Convention for the Suppression of the Financing of Terrorism and of the International Convention on the Elimination of All Forms of Racial Discrimination (Ukraine v Russian Federation) (Request for the Indication of Provisional Measures: Order) General List No 166 [2017] ICJ 1. See also Kimberley Trapp, 'Ukraine v Russia (Provisional Measures): State 'Terrorism' and IHL' EJIL: Talk! (2 May 2017) <www.ejiltalk.org/ukraine-v-russia-provisional-measures-state-terrorism-andihl/> accessed 4 May 2017; Iryna Marchuk, 'Ukraine's Dashed High Hopes: Predictable and Sober Decision of the ICJ on Indication of Provisional Measures in Ukraine v Russia' EJIL: Talk! (24 April 2017) $<$ www.ejiltalk.org/ukraines-dashed-high-hopes-predictable-and-sober-decision-of-the-icj-on-indication-ofprovisional-measures-in-ukraine-v-russia/> accessed 3 May 2017; Ministry of Foreign Affairs of Ukraine, 'The Hearing of the Case Ukraine v Russian Federation under UNCLOS will Start at the Beginning of 2017' (23 December 2016) <www.mfa.gov.ua/en/press-center/news/53422-na-pochatku-2017-roku-rozpochnetysyarozglyad-spravi-ukrajina-proti-rosijsykoji-federaciji-zgidno-z-konvencijeju-oon-z-morsykogo-prava $>$ accessed 3 May 2017.

${ }^{41}$ Sergejs Dilevka, 'Arbitration Claims by Ukrainian Investors under the Russia-Ukraine BIT: between Crimea and a Hard Place?' CIS Arbitration Forum (17 February 2016) $<$ www.cisarbitration.com/2016/02/17/arbitration-claims-by-ukrainian-investors-under-the-russia-ukraine-bitbetween-crimea-and-a-hard-place/> accessed 18 April 2017.

${ }^{42}$ UNCITRAL Arbitration Rules, UN Doc A/65/465 (2010).

${ }^{43}$ Stabil LLC and others $v$ Russian Federation, UNCITRAL, PCA Case No 2015-35; Lugzor LLC and others $v$ Russian Federation, UNCITRAL, PCA Case No 2015-29; PJSC Privatbank and Finance Company Finilion LLC v Russian Federation, UNCITRAL, PCA Case No AA568; Everest Estate LLC and others v Russian Federation, UNCITRAL, PCA Case No AA577; Aeroport Belbek LLC and Mr Igor Kolomoisky v Russian Federation, UNCITRAL, PCA Case No 2015-07; PJSC Ukrnafta v Russian Federation, UNCITRAL, PCA Case No 2015-34.

${ }^{44}$ Mutatis mutandis Netherlands v Russia, UNCLOS, PCA Case No 2014-02, Award on Jurisdiction of 26 November 2014, para 5 (The Arctic Sunrise Arbitration).

${ }^{45}$ Aeroport Belbek LLC and Mr Igor Kolomoisky v Russian Federation, UNCITRAL, PCA Case No 2015-07 (Pending) PCA Press Release 192615 (The Hague, 9 March 2017) <www.pcacases.com/web/sendAttach/1703> accessed 8 August 2017.

${ }^{46}$ ibid; PJSC Ukrnafta v Russian Federation, UNCITRAL, PCA Case No 2015-34 (Pending), Stabil LLC and others $v$ Russian Federation, UNCITRAL, PCA Case No 2015-35 (Pending) PCA Press Release 202236 (The
} 
awards themselves remain confidential, the significance of the tribunal's conclusions cannot be underestimated as this is believed to be the first time that a tribunal has found a BIT to be applicable in a territory regarded by the international community as illegally occupied. ${ }^{47}$

Prior to the phase on the merits, the investors submitted arguments on the matter of jurisdiction, ${ }^{48}$ namely the existence of an investment (ratione materiae) ${ }^{49}$ made in the 'territory' of a contracting state (ratione loci) ${ }^{50}$ at the time when the obligations were already in force (ratione temporis) by the investor - a national of the other contracting state (ratione personae). ${ }^{51}$ Under the Russia-Ukraine BIT, investment tribunals have jurisdiction over

any dispute between either Contracting Party and the investor of the other Contracting Party, which may arise in connection with the investments ... [that denote] ${ }^{52}$ all kinds of property and intellectual values put in by the investor of one Contracting Party in the territory of the other Contracting Party .... 53

This approach is conventional for bilateral as well as multilateral treaty instruments. ${ }^{54}$ Hence, to establish whether a treaty applies in the first place, it is necessary to tackle issues connected to the meaning of 'territory' and 'nationality', as well as to address concerns regarding temporality matters.

\section{b) Territoriality of investment treaties}

The term 'territory' in 'territory of the other Contracting Party ${ }^{, 55}$ may be interpreted as the 'entire territory ${ }^{, 56}$ within the actual and effective exercise of jurisdiction, ${ }^{57}$ or narrowed to the strict literal meaning ${ }^{58}$ of 'territory under the sovereignty' in some treaty instruments. ${ }^{59}$

Hague, 4 July 2017) <www.italaw.com/sites/default/files/case-documents/italaw9180.pdf $>$ accessed 8 August 2017.

${ }^{47}$ Alison Ross, 'Crimea Cases against Russia to Proceed' Global Arbitration Review (9 March 2017) <www. globalarbitrationreview.com/article/1137587/crimea-cases-against-russia-to-proceed> accessed 15 April 2017.

${ }^{48}$ Shabtai Rosenne, The World Court: What it is and How it Works ( $5^{\text {th }}$ edn, Martinus Nijhoff Publishers 1995) 283.

${ }^{49}$ Rudolf Dolzer and Christoph Schreuer, Principles of International Investment Law (2nd edn, OUP 2012) 60.

${ }^{50}$ Michael Waibel, 'Investment Arbitration: Jurisdiction and Admissibility' (2014) University of Cambridge Legal Studies Research Paper 9/2014 <www.ssrn.com/abstract=2391789> accessed 9 July 2016.

${ }^{51}$ Douglas (n 27) paras 297, 616.

${ }^{52}$ Agreement between the Government of the Russian Federation and the Cabinet of Ministers of Ukraine on the Encouragement and Mutual Protection of Investments (signed 27 November 1998, entered into force 26 January 2000) ('Russia-Ukraine BIT') art 9(1).

53 ibid art 1.

${ }^{54}$ NAFTA, arts 1(7), 10, 13, 26; ECT, arts 1101-16.

${ }^{55}$ Douglas (n 27) para 285.

${ }^{56}$ Vienna Convention on the Law of Treaties (adopted 23 May 1969, entered into force 27 January 1980) 1155 UNTS 331 (VCLT) arts 15, 29, 31.

${ }^{57}$ Ian Brownlie, Principles of Public International Law (7th edn, OUP 2008) 112. See also International Covenant on Civil and Political Rights (16 December 1966) 999 UNTS 171 (adopted 16 December 1966, entered into force 23 March 1976) (ICCPR) art 2.

${ }^{58}$ Burgos v Uruguay (1981) Selected Decisions of the Human Rights Committee 88.

${ }^{59}$ ECT, arts 1(10)(a), 26(1). 
The Russia-Ukraine BIT's articulation of this element regards 'the territory of the Russian Federation or the territory of Ukraine and also their respective exclusive economic zone and the continental shelf as defined in conformity with the international law, ${ }^{60}$ Therefore, in strict legal terms, economic contributions made by the investors of Ukrainian nationality in the territory of Crimea - a part of Ukraine - cannot be characterised thus protected as investments within the ordinary meaning of the BIT terms. ${ }^{61}$ This broad definition brings into play different instruments and sources of international law, such as investment treaties and customary international law on territoriality and state succession. As to the former, article 12 of both the Russian and the Ukrainian original BIT texts ${ }^{62}$ read as follows: ' $[\mathrm{t}]$ he agreement shall apply to all investments carried out by the investors of one Contracting Party in the territory of the other Contracting Party, as of January 1, 1992'. ${ }^{63}$ Thus, the main concern arising therefrom is whether the Russia-Ukraine BIT extends its application to the territories acquired by either of the contracting parties. ${ }^{64}$

There are relevant policy considerations involved in this exercise of treaty construction, concretely regarding its extended application to all investments in a state's entire territory, ${ }^{65}$ including territory which is subsequently annexed through legal or illegal means. Particularly, there is a plausible, pragmatic - insofar as it would enable the protection of individual investors - argument favouring the idea of characterising Crimea as Russian territory, at least since the formal annexation took place.

Putting forward the customary international law argument, the principles of succession support the extended application only if consistent with the ordinary meaning, object and purpose of the treaty ${ }^{66}$ and insofar as it does not fundamentally change the conditions of operation. ${ }^{67}$

The purpose of the investment treaty regime is to protect investors and to promote

\footnotetext{
${ }^{60}$ Russian-Ukraine BIT (n 52) art 1.

${ }^{61}$ VCLT, arts 31(1), 32.

${ }^{62}$ Russia-Ukraine BIT (n 52) art 14(3).

63 ibid art 12.

${ }^{64}$ Victoria Ishchenko, 'How to Obtain Compensation for the Lost Investment in the Annexed Crimea?' (Ukrainian Bar Association, 4 August 2017) <www.youtube.com/watch?v=EKoxujVljP0\&feature=youtu.be $>$ accessed 8 August 2017.

${ }^{65}$ The term 'extended application' of investment treaties is attributed to Happ and Wuschka (n 13). The authors argue that rules on the succession of treaties allow extended application of investment treaties under certain circumstances, including when it accords the object, purpose of the treaty and extends the conditions of operation. That, according to the authors, constitutes a pragmatic approach to the extension of the Russian investment treaties to the territory of Crimea.

${ }^{66}$ VCLT, arts 31(1), 32. See also Sanum Investments Ltd v Laos, UNCITRAL, PCA Case No 2013-13, Award on Jurisdiction of 13 December 2013, para 230 (Sanum PCA).

${ }^{67}$ Sanum PCA (n 66) para 87.
} 
economic cooperation. ${ }^{68}$ Thus, it arguably favours the extended application of the treaty that covers investments in the area expanded that includes the annexed territory, so as to include investors which would otherwise be deprived of protection. This idea was underlined in Sanum Investments Ltd $v$ Laos. In that case, the tribunal held that depriving Macanese investors of the protection granted by one hundred thirty BITs of the People's Republic of China (PRC) would leave only a few investors protected under two BITs concluded by Macao. ${ }^{69}$

However, the landscape of protection in the Crimea situation is different. As simultaneously developed investment frameworks, Ukraine and Russia - former Soviet Union republics - feature sixty-three BITs in force concluded by the latter and fifty-seven by the former with similar versions of the boilerplate rules concerning their operation and level of protection.

For example, British ${ }^{70}$ and Austrian ${ }^{71}$ investors in Crimea ${ }^{72}$ could possibly rely on the BITs with either Ukraine or Russia. For them, either construction would yield protection, at least in the abstract. Conversely, other foreign investors, including those from Georgia and the US would be deprived of protection if the extended (pragmatic) construction were favoured. This is due to the absence of investment treaties in force between those states and the Russian Federation. Finally, recourse to multilateral treaty instruments, in particular the Energy Charter Treaty (ECT), is limited due to the termination of its provisional application by the Russian Federation. ${ }^{73}$ Consequently, succession of investment treaties may apply if it accords to the purpose of the treaty and does not limit the existing level of protection. ${ }^{74}$

\footnotetext{
${ }^{68}$ Douglas (n 27) para 234.

${ }^{69}$ Sanum PCA (n 66) para 107.

${ }^{70}$ Agreement between the Government of the United Kingdom of Great Britain and Northern Ireland and the Government of the Union of Soviet Socialist Republics for the Promotion and Reciprocal Protection of Investments (signed 6 April 1989, entered into force 3 July 1991) (UK-Soviet BIT) arts 1(a)(d)(e), 2; Agreement between the Government of the United Kingdom of Great Britain and Northern Ireland and the Government of Ukraine for the Promotion and Reciprocal Protection of Investments (signed 10 February 1993, entered into force 10 February 1993) (UK-Ukraine BIT) arts 1(a)(c), 2.

${ }^{71}$ Agreement between the Federal Government of the Russian Federation and the Government of the Republic of Austria for the Promotion and Reciprocal Protection of Investments (signed 8 February 1990, entered into force 1 September 1991) (Russia-Austria BIT) arts 1(1)(a)(b), 2; Agreement between the Government of the Republic of Austria and the Government of Ukraine for the Promotion and Reciprocal Protection of Investments (signed 8 November 1996, entered into force 1 December 1996) (Austria-Ukraine BIT) arts 1(1)(2)(6), 2.

${ }^{72}$ State Statistics Service of Ukraine, Annual Report of the Foreign Direct Investment in Ukraine (State Statistics Service of Ukraine 2014).

${ }^{73}$ Energy Charter Protocol on the Questions of Energy Efficiency and Corresponding Ecological Aspects, Federal Decree of the Russian Federation No 1055-p of 30 July 2009.

${ }^{74}$ Luis Gonzales Garcia, 'Comparing with Famous. Why Crimea is not Kosovo and Relevance of Comparison from the Prospective of International Law' Juridicheskaya Praktika (Kyiv, 20 May 2014) <www.pravo.ua/article.php?id=100109207> accessed 21 July 2017.
} 
A tribunal may also look for an alternative argumentation and analyse all references to the meaning of the relevant treaty instrument. For instance, article 1(1) of the Russia-Ukraine BIT reads as follows: 'investments shall denote all kinds of property and intellectual values, which are put in by the investor of one Contracting Party in the territory of the other Contracting Party in conformity with the latter's legislation' ${ }^{75}$ In addition, article 2 contains a reference to the mutual obligation of each contracting party to guarantee, in conformity with its legislation, the complete and unconditional legal protection of investments and investors of the other contracting party. ${ }^{76}$ In the context of these provisions as well as customary international law, ${ }^{77}$ it is possible to conclude that the territory, pursuant to the applicable treaty wording, shall denote any piece of land where either of contracting parties exercises its legal and regulatory control, including any subsequently acquired or incorporated territory.

It is doubtful whether determining the applicability of the Russia-Ukraine BIT requires a decision on the legality of the territorial acquisition within a meaning of article 1(4). This is because the Russian and the Ukrainian original BIT texts may be read differently when compared with the English translation. Whilst the English version of article 1(4) refers to the term 'territory' defined in conformity with international law, the comma placed in the original Russian and the Ukrainian texts ${ }^{78}$ allows for a different interpretation. Both original texts may be read in a way to provide that only the parties' respective exclusive economic zone and the continental shelf shall be defined in conformity with international law whereas territory means 'the territory of the Russian Federation or the territory of the Ukraine'. ${ }^{79}$

Had the tribunal decided to bring articles 15, 29, 31 and 32 of the VCLT into play, Russian investment treaties would be automatically applicable in the territory of Crimea, unless any of the established exceptions are deemed relevant. This interpretation arguably accords the inclusive wording of the applicable investment treaty as well as its parties' intentions to grant the widest possible protection in order to strengthen mutual economic ties.

Furthermore, this approach allows for the avoidance of the need to elaborate on the international illegality argument and to answer the main question put before the tribunal, which is whether this treaty is applicable to the new territorial units acquired by either contracting state.

\footnotetext{
${ }^{75}$ Russia-Ukraine BIT (n 52) art 1(1).

${ }^{76}$ ibid art 2(2).

77 VCLT, art 29.

${ }^{78}$ Russia-Ukraine BIT (n 52) art 14.

${ }^{79}$ ibid art 1(4).
} 
Finally, in accordance with the principle pacta sunt servanda, the Russian Federation that incorporated the Crimean Peninsula into its federal structure shall be liable for nonfulfilment of any legal obligation arising out of that incorporation, including its investment treaties.

\section{Limitations to the approach of the treaty extension to annexed territories}

a) Time limitations

Another question put before the tribunal regards the implications of the scenario in which a state exercising legal control over the territory at the time when investments are made is different to a state controlling part of its territory at the moment of expropriation. It may be argued that starting from March 2014, when the Russian Federation ratified the Crimea Agreement, all investments in the territory of Crimea became foreign investments for Ukraine and domestic for Russia.

According to article 12 of the Russia-Ukraine BIT: '[t]his Agreement shall apply to all investments carried out by the investors of one Contracting Party in the territory of the other Contracting Party, as of January 1, 1992 ${ }^{80}$ Historically, this date is related to the dissolution of the Soviet Union. ${ }^{81}$ Hence, regardless the fact that this agreement was entered into in November 1998 and came into force in January 2000, ${ }^{82}$ all investments made after January 1, 1992 were to be retrospectively protected under its provisions.

There are some important discrepancies in the wording of articles 1(1) and 12 of this agreement. In contrast to the terms 'carried out' used in article $12^{83}$ vis-à-vis past continuous actions, the term 'put in' used in relation to investments in article 1(1) places a complete performance requirement in past time. ${ }^{84}$ Conversely, the Russian and Ukrainian original texts of article 1(1) use the present continuous tense of 'carrying out' in regards to investments. ${ }^{85}$

Taking into account the general retrospective effect of this treaty, its wording may be interpreted in support of the position favouring continuation of investment, in contrast with the requirement of investing in the territory of another contracting state $a b$ initio. Based on this analysis there may be no need to define the exact moment in time when the protected investments were made and for what period as long as these occurred after January 1, 1992.

\section{b) Investors and investments}

Nationality of an investor is a precondition for the existence of protected investment

\footnotetext{
${ }^{80}$ ibid art 12.

${ }^{81}$ George Breslauer, Gorbachev and Yeltsin as Leaders (CUP 2002) 274.

${ }^{82}$ Russian-Ukraine BIT (n 52) art 14(1)-(3).

83 ibid art 12 .

${ }^{84}$ ibid art 1(1).

85 ibid.
} 
under the investment treaty. The Russia-Ukraine BIT protects the investments by Ukrainian nationals and companies owned and controlled by Ukraine ${ }^{86}$ carried out in the territory of the Russian Federation in conformity with its legislation and vice versa. ${ }^{87}$

Thus, Ukrainian nationals and corporate entities registered in Ukraine may be required to prove that their investment is recognised under Russian law. Regulations dated 25 July $2014^{88}$ and 31 July $2014^{89}$ adopted by the Crimean federal authorities may be of assistance. These acts provide that the Russian Federation recognised all licences and permits issued by the Ukrainian authorities and, consequently, all property rights attached to these documents. In addition, the Federal Constitutional $\mathrm{Act}^{90}$ adopted by Russia simultaneously with the ratification of the Crimea Agreement ${ }^{91}$ provides that all documents issued by the state authorities of Ukraine are recognised and valid in the territory of the Russian Federation. These provisions create a solid ground for arguing that investments by Ukrainian companies and individuals in Crimea are carried out in accordance with Russian law.

It should be noted that some of the claimants in ongoing arbitration proceedings involving Ukrainian companies are in fact foreign shareholders. ${ }^{92}$ As such, these shareholders might fall under the scope of several investment treaties, for example those entered into by their state of nationality, therefore providing a distinct basis on which to bring a claim against the Russian Federation'. ${ }^{93}$ However, the scope of shareholders' protection depends on the terms of the respective treaty ${ }^{94}$ and the ratione temporis link between the unlawful expropriation and the time when the investment was made. ${ }^{95}$ Consequently, the purchase of shares made after the illegal act took place will be outside of the ratione temporis jurisdiction

\footnotetext{
${ }^{86}$ PJSC PrivatBank (n 43).

${ }^{87}$ Dilevka (n 41).

${ }^{88}$ On Regulation of Property and Land Relations in the Territory of the City of Sevastopol, Law of the city of Sevastopol No 46-AP of 25 July 2014.

${ }^{89}$ On Management of Property and Land Relations in the Territory of the Republic of Crimea, Law of the Republic of Crimea No 38-3PK of 31 July 2014 (as amended on 15 March 2016) art 1.

${ }^{90}$ On the Incorporation of the Republic of Crimea into the Russian Federation and the Establishment of New Units of the Russian Federation - the Republic of Crimea and the City of the Federal Significance of Sevastopol, Federal Constitutional Law of the Russian Federation No 6-FKZ of 21 March 2014 art 12.

${ }^{91}$ Crimea Agreement (n 12).

${ }^{92}$ State Register Service, 'Private Company Registration Database' (Ministry of Justice of Ukraine, 14 January $2015)<$ www.usr.minjust.gov.ua/ua/freesearch> accessed 19 August 2016.

${ }^{93}$ Enron Corp and Ponderosa Assets, LP v Argentina, ICSID Case No ARB/01/3, Decision on Jurisdiction (Ancillary claim) of 14 January 2004; Siemens $A G v$ Argentina, ICSID Case No ARB/02/8, Decision on Jurisdiction of 3 August 2004; Waste Management Inc v Mexico, ICSID Case No ARB(AF)/00/3, Award of 30 April 2004 (Waste Management).

${ }^{94}$ Tokios Tokelés tribunal held that a company incorporated in Lithuania was entitled to bring a claim against Ukraine under the Lithuania-Ukraine BIT, although it was controlled and ninety-nine per cent owned by Ukrainian nationals in Tokios Tokelés (n 30) para 18.

${ }_{95}^{95}$ RosInvestCo UK Ltd v Russian Federation, SCC Arbitration V (079/2005), Final award of 12 September 2010, para 162 (RosInvest Merits); Levi and Gremcitel v Peru, ICSID Case No ARB/11/17, Award of 9 January 2015, paras 140-61.
} 
of a constituted tribunal.

Taking this approach, UK shareholders of Rubenor LLC - the Claimant in one of the pending disputes ${ }^{96}$ - may also consider protecting their assets and share purchase under the Agreement between the Government of the United Kingdom and the Government of the Union of Soviet Socialist Republics (UK-Soviet BIT).${ }^{97}$ Invocation of ECT provisions on the protection of foreign shareholdings - an argument put forward by some commentators ${ }^{98}$ seems to not be a valid option as the Russian Federation has never ratified that treaty. ${ }^{99}$ Moreover, in 2009 Russia terminated the ECT provisional application and stated its intent not to become a party thereto, ${ }^{100}$ arguably due to its long-lasting arbitration with Yukos Universal Ltd. ${ }^{101}$ Thus, this option is unhelpful from a temporal perspective as the Crimean events leading to expropriation allegedly commenced in 2014 and hence fall outside of the temporary provisional application of the treaty.

c) International illegality

The Sanum v Laos tribunal decided to extend the application of the PRC treaties to the Macao administrative region based on the purpose and wording of the PRC-Laos BIT. Firstly, the tribunal was dealing with the application of the treaties which third parties concluded after the acquisition of Macao. Secondly, the handover of Macao represents the resumption by the PRC to exercise its sovereignty over Macao. ${ }^{102}$ In the Crimea scenario, Ukraine and other possibly affected states explicitly objected to the legality of the acquisition when it occurred, continuing to sanction it up to present.

The extension of one state's treaties to acquired territory formerly part of another state depends on the legal status of territorial acquisition. ${ }^{103}$ This condition was emphasised in the Sanum v Laos Judgment of Singapore's High Court. ${ }^{104}$ The international community cannot

\footnotetext{
96 Stabil LLC (n 43).

${ }^{97}$ RosInvest Merits (n 95) para 165.

${ }^{98}$ Odysseas G Repousis, 'Why Russian Investment Treaties Could Apply to Crimea and What Would This Mean for the Ongoing Russo-Ukrainian Territorial Conflict' (2016) 32 Arb Intl 2016, 459-481.

${ }^{99}$ Shareholders of the Crimea-Petrol LLC in Stabil LLC and the Claimant in PJSC Ukrnafta (n 43); ECT, art $1(6)$.

${ }^{100}$ Irina Pominova, Risks and Benefits for the Russian Federation from Participating in the Energy Charter: Comprehensive Analysis (Energy Charter Secretariat Knowledge Centre, 2014) $<$ www.energycharter.org/fileadmin/DocumentsMedia/Occasional/Russia_and_the_ECT_en.pdf $>$ accessed 25 July 2017.

${ }^{101}$ Yukos Universal Limited (Isle of Man) v Russian Federation, UNCITRAL, PCA Case No AA 227, Final Award of 18 July 2014 (Yukos PCA).

102 Sanum PCA (n 66) paras 81-110.

${ }^{103}$ Vienna Convention on Succession of States in Respect of Treaties (adopted 23 August 1978, entered into force 6 November 1996) 1946 UNTS 3 (VCSS) arts 6, 15.

${ }^{104}$ Government of the Lao People's Democratic Republic v Sanum Investments Ltd [2015] SGHC 111 (Sanum $S G H C)$.
} 
legitimise unlawful annexation, ${ }^{105}$ as the illegal use of force constitutes a violation of the Charter of the United Nations. ${ }^{106}$

Hence, Doering's, ${ }^{107}$ Happ's and Wuschka's ${ }^{108}$ pragmatic approach to the extension of investment treaties to "so-called dependent territories" ${ }^{109}$ cannot be justified as it is contrary to international law. ${ }^{110}$ Formulated differently, the treaty succession principles do not operate in complete isolation of sovereignty considerations under international law, nor do they regard foreign investment law as a self-contained regime.

Should the tribunal choose to restrain from elaboration on the illegality argument, it may develop an alternative approach of analysis. This approach is built upon the literal and contextual reading of the treaty as well as the reciprocal guarantees of contracting parties to create and maintain favourable conditions for mutual investments on their respective territories. It allows for Russia to be deemed liable for all actions directed at expropriation of investments after ratification of the Crimea Agreement.

\section{EUROPEAN COURT OF HUMAN RIGHTS AND THE PROTECTION OF INVESTORS IN CRIMEA}

The relationship between the parties in a foreign investment dispute settlement bears a strong resemblance to the relationship arising out of human rights claims as both regimes originate in the law of state responsibility dealing with legal relationships between individuals and states. ${ }^{111}$ The human rights regime provides a model for protection of individual and corporate investors' rights, as well as a more settled solution to the question of the attribution of extraterritorial unlawful conduct.

\section{The human rights protection framework}

a) Subject and object of human rights protection

As previously suggested, the object of the investment regime to some extent accords with the purpose of the human rights framework: to protect individual rights and property. It is

\footnotetext{
${ }^{105}$ UNGA 'Declaration on the Strengthening of International Security' UNGA Res 2734 (XXV) (16 December 1970) UN Doc A/RES/2734(XXV) para 2.

${ }^{106}$ Charter of the United Nations (adopted 26 June 1945, entered into force 24 October 1945) 892 UNTS 119 (UN Charter) art 2(4).

${ }^{107}$ Karl Doehring, 'The Scope of the Territorial Application of Treaties - Comments on Art 25 of the ILC's 1966 Draft Articles on the Law of Treaties' (1967) 27 H J Intl L 483, 488.

${ }^{108}$ Happ and Wuschka (n 13) 245.

${ }^{109}$ Treaty of Amity, Economic Relations and Consular Rights between the United States and the Sultan of Muscat and Oman (US-Muscat-Oman) (adopted 20 December 1958, entered into force 11 June 1960) 380 UNTS 181.

${ }^{110}$ UNGA Res 68/262 (n 13) para 5.

${ }^{111}$ International Thunderbird Gaming Corporation v United Mexican States, UNCITRAL, NAFTA arbitration, Separate Opinion of Thomas Wälde of 1 December 2005, para 13.
} 
commonplace for investors to seek protection under both regimes. ${ }^{112}$ More than twenty individual applications have been submitted to the European Court of Human Rights $(\mathrm{ECtHR})^{113}$ in addition to an inter-state application filed by Ukraine against Russia. ${ }^{114}$

As Council of Europe Members, Ukraine and Russia participate in the Council's structures including the ECtHR. ${ }^{115}$ The ECtHR has jurisdiction to decide on complaints concerning violations of the ECHR allegedly committed by a state party to the Convention that directly and significantly affected the applicant. ${ }^{116}$

The protection of investors under this legal framework mainly concerns the right to property, as guaranteed by Protocol No 1 to the ECHR (Protocol I). It is concerned with peaceful enjoyment of possession, protection from deprivation, and the right to control the use of property. ${ }^{117}$ Although there is no explicit notion of the term 'expropriation' in the Convention, the ECtHR has provided guidance in its case law on whether measures taken by a state amount to expropriation ${ }^{118}$ as opposed to merely taking of control or discriminatory treatment. ${ }^{119}$ Procedurally speaking, states, individuals or groups of individuals may file applications before the ECtHR. ${ }^{120}$ Further analysis on these matters is offered below.

\section{b) General requirements of the inter-state and individual applications mechanisms}

The erga omnes nature of the interests protected by human rights treaties ensures a member state's right to act without any direct interest but rather to enforce the European public order. ${ }^{121}$ Hence, a state does not need to demonstrate any particular direct or indirect legal interest or to submit an application on behalf of an individual in order to trigger proceedings vis-order another state. Inter-state application requirements include the statement of facts and

\footnotetext{
${ }^{112}$ OAO Neftyanaya Kompaniya Yukos v Russia App no 14902/04 (ECtHR, 31 July 2014) (Yukos ECtHR); Yukos PCA (n 101) para 1827.

${ }^{113}$ ECtHR Press Release, 'European Court of Human Rights deals with cases concerning Crimea and Eastern Ukraine' (26 November 2014) ECHR 345 (2014).

${ }^{114}$ ECtHR Press Release, 'European Court of Human Rights communicates to Russia new inter-State case concerning events in Crimea and Eastern Ukraine’ (1 October 2015) ECHR 296 (2015).

${ }^{115}$ Alexey Arbatov and Andrei Kolesnikov, 'Does Russia Need the Council of Europe?' Carnegie Endowment for International Peace (4 February 2015) <www.carnegieendowment.org/2015/02/04/does-russia-needcouncil-of-europe $>$ accessed 21 August 2016.

${ }^{116}$ Karen Reid, A Practitioner's Guide to the European Convention on Human Rights (2nd edn, Sweet \& Maxwell 2010) 243.

${ }^{117}$ Convention for the Protection of Human Rights and Fundamental Freedoms (European Convention on Human Rights, as amended) (ECHR) art 1; Protocol No 1 of the Convention for the Protection of Human Rights and Fundamental Freedoms (adopted 4 November 1950, entered into force 3 September 1953) 213 UNTS 222 (Protocol I) art 1. See also Rosalyn Higgins, 'The Taking of Property by the State: Recent Developments in International Law' (1982) 176 Recueil des Cours de l'Académie de Droit International 259, 345.

${ }^{118}$ Campbell McLachlan, Laurence Shore and Matthew Weiniger, International Investment Arbitration: Substantive Principles (OUP 2010) 288.

${ }^{119}$ Paparinskis (n 24) 220-23; Vasilescu v Romania App 27053/95 (ECtHR, 22 May 1998), paras 47-48.

${ }^{120}$ William A Schabas, The European Convention on Human Rights. A Commentary (OUP 2015) 720-23.

${ }^{121}$ Henry Steiner, Philip Alston and Ryan Goodman, International Human Rights in Context (3rd edn, OUP 2015) 213.
} 
alleged conventional breaches, as well as the applicant's fulfilment of admissibility requirements. $^{122}$

Conversely, an individual applicant must claim to be a victim directly affected by the impugned measure. ${ }^{123}$ Similarly, an individual application must contain a statement of relevant facts, alleged violations and compliance with admissibility criteria. ${ }^{124}$ Having established the competence to deal with the matter laid before it on a preliminary basis, ${ }^{125}$ the ECtHR should consider the fulfilment of jurisdiction and admissibility criteria. This article deals only with issues which are problematic in the factual context of the Crimea case study.

\section{Jurisdiction of the ECtHR}

a) Principle of extraterritoriality in human rights

A state's jurisdictional competence under the human rights regime is primarily territorial. ${ }^{126}$ In contrast to the currently unsettled practice of investment arbitration tribunals, the human rights regime has already developed extraterritorial solutions for cases involving an annexation-like scenario. ${ }^{127}$ This principle is based on the premise that 'acts of the Contracting states performed, or producing effects, outside their territories can constitute an exercise of jurisdiction within the meaning of article $1^{, 128}$ under the personal and territorial models of jurisdiction developed for the specific purpose of determining whether a treaty applies extraterritorially.

The personal model is concerned with inter alia the state's authority through diplomatic and consular establishments, use of force and exercise of public powers. ${ }^{129}$ The territorial model triggers the human rights violations within the occupied territory of the ECHR espace juridique, but also beyond the territory of ECHR member states as developed in the ECtHR post-Banković case law. ${ }^{130}$ The approach taken in Banković is distinguishable from the ECtHR's subsequent case law but should still be considered as relevant where both states are the ECHR Parties.

\footnotetext{
${ }^{122}$ ECHR, art 33.

${ }^{123}$ Vallianatos and others $v$ Greece GC App no 29381/09 (ECtHR, 19 February 2013), para 47.

${ }^{124}$ ECHR, art 34.

${ }^{125}$ Georgia v Russia App no 38263/08 (ECtHR, 13 December 2011), para 64.

${ }^{126}$ Banković and others v Belgium and others App no 52207/99 (ECtHR, 12 December 2001), paras 61, 67; Ilaşcu and others v Moldova and Russia App no 48787/99 (ECtHR, 8 July 2004), para 312; Assanidze v Georgia App no 71503/01 (ECtHR, 8 April 2004), para 139.

${ }^{127}$ Marko Milanovic, Extraterritorial Application of Human Rights Treaties: Law, Principles and Policy (OUP 2011).

${ }^{128}$ Banković (n 126) para 67.

${ }^{129}$ Cyprus v Turkey App no 25781/94 (ECtHR, 10 May 2001), para 77.

${ }^{130}$ Loizidou $v$ Turkey App no 15318/89 (ECtHR, 23 March 1995), para 52; Banković (n 126); R (Al-Skeini) $v$ Secretary of State for Defence [2007] UKHL 26, [2008] 1 AC 153; Jaloud $v$ The Netherlands App no 47708/08 (ECtHR, 20 November 2014).
} 
b) Instrumental character of human rights law in the context of the protection of investors

Referring to the discussion at the beginning of this article, irrespective of the legality of territorial acquisition, investors whose property was expropriated in that territory must be protected. ${ }^{131}$ Under the principle of extraterritoriality, international obligations may be owed by states outside their borders insofar as the relevant conduct occurs within a state's respective 'jurisdiction'. Thus, if treaty obligations are invoked extraterritorially, the relevant adjudicatory body will have to determine whether the conduct at issue occurred within the jurisdiction of the relevant state. ${ }^{132}$ There are two main approaches on ascertaining whether obligations are owed extraterritorially: the personal model of jurisdiction and the territorial model of jurisdiction.

Under the personal model of jurisdiction, acts of the state agents committed in their official capacity ${ }^{133}$ may render certain obligations applicable with respect to persons under their control even if that conduct took place abroad. For instance, in Lopez Burgos $v$ Uruguay, Uruguay was found liable for violations of the International Covenant on Civil and Political Rights ('ICCPR'). ${ }^{134}$ The conduct involved the kidnapping and torture of Argentinian victims committed in Argentina but perpetrated by Uruguayan agents. It was found that the victims were in those instances under Uruguay's jurisdiction. ${ }^{135}$ Accordingly, the personal model is a likely option for an arbitral tribunal to adopt in order to avoid making pronouncements on the illegality argument when asserting its jurisdiction. Instead, the personal model would enable a tribunal work around the de facto control of Crimea by Russia. $^{136}$

Two potential problems arise. It may be problematic from both a factual and an evidentiary perspective to argue that illegal actions of informal groups ${ }^{137}$ against investors in Crimea would be attributable to Russia, as they will likely not satisfy the applicable threshold. According to the complete dependence control test established by the International Court of Justice in Nicaragua $v U S$, if states carry out actions through private individuals

\footnotetext{
${ }^{131}$ Happ and Wuschka (n 13) 245.

${ }^{132}$ ECHR, art 1; International Covenant on Civil and Political Rights (adopted 16 December 1966, entered into force 23 March 1976) 999 UNTS 171 (ICCPR) art 2(1).

${ }^{133}$ The Claims of Rosa Gelbtrunk and the Salvador Commercial Company (El Salvador v United States) (1902) 15 RIAA 455.

${ }^{134}$ Burgos (n 58).

135 ibid para 13.

${ }^{136}$ Ross (n 47).

${ }^{137}$ Howard Amos, 'Russia Signals End to Crimea Property Grab, but Investors Unlikely to Bite' The Moscow Times (17 February 2015) <www.themoscowtimes.com/articles/russia-signals-end-to-crimea-property-grab-butinvestors-unlikely-to-bite-43989> accessed 19 August 2016.
} 
under their direction and control, they will be liable under international law for conduct committed by those individuals. ${ }^{138}$ However, the threshold for attributing serious violations of international law by individuals to the state is high. In Nicaragua $v$ US, the Court established that actions of US organs aimed at arming, training and equipping the rebels are sufficient for the purpose of attribution, but held that merely financing the rebels is not. ${ }^{139}$ Providing evidence sufficient to clear the threshold necessary for the personal model of jurisdiction would be problematic due to the nature of the facts and events in the Crimea scenario.

Furthermore, it is controversial whether the expropriation by Crimean local authorities could be attributable to Russia and, if so, since what point in time that would be so. If the local authorities of Crimea can be regarded as the state authorities since the entry into force of the Crimea Agreement, ${ }^{140}$ then all illegal actions of the local government of Crimea committed before this date will be attributable to Ukraine. Hence, the personal jurisdiction framework of analysis leaves a gap in the protection of investors. This is because protection would be subject to fine and delicate determinations as to which acts of Crimean authorities are attributable to Russia and which ones to Ukraine at any given point in time.

As to the territorial model of jurisdiction, obligations are triggered where a state establishes effective control of another state's territory. ${ }^{141}$ The ECtHR in Loizidou v Turkey ${ }^{142}$ and Cyprus $v$ Turkey ${ }^{143}$ held that where a state exercises de facto effective control over another state's territory through its agents, third parties, including a subordinate local administration acting under its direction, it may be responsible for illegal acts committed in the territory under its effective control. ${ }^{144}$ For the purposes of extraterritorial application of investment treaties, this would mean that no protection is granted until Russia put the territory of Crimea under its de facto control. Again, the critical date of this is very speculative due to evidentiary considerations. ${ }^{145}$

\footnotetext{
${ }^{138}$ Case Concerning Military and Paramilitary Activities in and Against Nicaragua (Nicaragua v United States) (Judgment) [1986] ICJ Rep 14.

${ }^{139}$ ibid [99]-[115].

${ }^{140}$ Crimea Agreement (n 12).

${ }^{141}$ James Crawford, State Responsibility: The General Part (CUP 2013) 2.1.2.

${ }^{142}$ Loizidou (n 130) para 52.

${ }^{143}$ Cyprus (n 129) para 77.

${ }^{144}$ Loizidou (n 130) paras 62-64.

${ }^{145}$ However, the ICJ may bring some clarity in this regard depending on what transpires in the fact-finding portion of the debate between the parties in the ongoing case concerning the Application of the International Convention for the Suppression of the Financing of Terrorism and of the International Convention on the Elimination of All Forms of Racial Discrimination (Ukraine v Russian Federation) (Pending) ICJ press release 2017/24 <www.icj-cij.org/files/case-related/166/166-20170614-PRE-01-00-EN.pdf> accessed 21 July 2017.
} 
Hence, the direct investor-state system grants protection to individual investors in respect of their investment rights defined under the relevant framework. The principle of nonlegitimisation of illegally acquired territory precludes treaty succession. However, the flexibility of the system allows for consideration of the international rules on extraterritoriality in the context of investors' protection. Both major models of extraterritorial jurisdiction raise serious concerns vis-à-vis their capacity to achieve the policy that underpins this approach: providing protection to investors in the broadest sense possible. Concretely, this is because of the inherent uncertainty regarding the temporal moment in which the treaty providing the legal basis for protection starts to be applicable extraterritorially in the first place. Although, provided that evidence allows a more flexible position to be established and the third party intervention is providing arguments in support of such position, investor-state arbitration may provide redress even in such complex and contradictory political scenarios. Helpful to some and unhelpful to others, this approach, however, does not add certainty in this system of international dispute resolution.

The personal model of jurisdiction in the human rights context may hardly be applicable in the Crimea scenario because of the lack of evidence implicating Russian military troops partaking in the annexation. ${ }^{146}$ Moreover, establishing control of the Russian Federation over those actions would not be enough to attribute the actual property deprivation or other discriminatory actions against investors to Russia. ${ }^{147}$

Firstly, this is due to the fact that the determination of the exact time when consent, invitation or acquiescence of the Crimea Government to transfer its authority in part or in full to Russia is highly complex from an evidentiary perspective. Secondly, all discriminatory actions against investors that are not committed by the agents of Russia under the personal model will not be attributable to Russia. ${ }^{148}$

The territorial model would apply through the exercise of governmental authority elements by the Russian Federation in Crimea and its control over the foreign investors (or investments). Importantly, in comparison to the investment treaty regime, the legal status of the Russian occupation is not determinative of the question of jurisdiction. ${ }^{149}$ As emphasised in Al-Skeini, "whenever the State through its agents exercises control and authority over an individual, and thus jurisdiction, the State is under an obligation to secure to that individual

\footnotetext{
${ }^{146}$ Loizidou (n 130) para 56.

${ }^{147}$ Cyprus (n 129) para 77.

148 Jaloud (n 130) para 119.

149 ibid para 142 .
} 
the rights and freedoms under ... the Convention ...' ${ }^{150}$ Hence, the Russian Federation may be found responsible for violations of the ECHR outside its sovereign territory in respect of the individual holder of the rights and freedoms protected by the Convention.

This important implication of the ECHR, which guarantees a wider scope of protection than the Russia-Ukraine BIT and multilateral instruments has a twilight zone for the Ukrainian Government. As the so called 'separatist' regime had been allegedly established in Crimea before the Russian military invasion, Ukraine may also be liable under the ECHR for its failure to ensure property rights of investors within its territory. ${ }^{151}$

\section{c) Nationality of individual applicants}

A certain nationality is not a requirement for the protection of property under the ECHR. The protection may be granted on an extraterritorial level, ${ }^{152}$ following the case law of the ECtHR, be it the Banković standard of espace juridique, ${ }^{153}$ which would still be applicable in this instance, or a more advanced standard defined in inter alia Al-Skeini ${ }^{154}$ and confirmed in Jaloud. $^{155}$

Articles 1 and 34 of the ECHR and article 5 of Protocol ${ }^{156}$ provide that everyone's rights and freedoms within the Contracting Parties' jurisdiction shall be protected and any victim of a violation committed by the Contracting Parties may file an application. Therefore, the standards of protection apply in the same manner for nationals and non-nationals of the ECHR Contracting states, ${ }^{157}$ both natural and legal persons. ${ }^{158}$

While practice concerning individual applications filed by natural and legal persons is settled, shareholders' standing to do so is a subject of debate. This is due to the nature of shareholding as a protected right ${ }^{159}$ and its relation to the particular company's business. ${ }^{160}$ As far as shareholding relates to the ownership of shares in a corporation ${ }^{161}$ and corresponding rights to vote or to receive dividends and claim company's residual assets after

\footnotetext{
${ }^{150} R$ (Al-Skeini) (n 130).

${ }^{151} \mathrm{Ilaşcu}$ (n 126).

${ }^{152}$ Ursula Kriebaum, 'Is the European Court of Human Rights an Alternative to Investor-state Arbitration?' in Pierre-Marie Dupuy, Ernst-Ulrich Petersmann and Francesco Francioni (eds), Human Rights in International Investment Law and Arbitration (OUP 2009).

${ }^{153}$ Loizidou (n 130) para 78; Banković (n 126) para 80.

${ }^{154} R$ (Al-Skeini) (n 130).

${ }^{155}$ Jaloud (n 130).

${ }^{156}$ ECHR, arts 1, 34; Protocol I, art 5.

${ }^{157}$ Kriebaum (n 152).

${ }^{158}$ Protocol I, art 1.

${ }^{159}$ Agrotexim and others $v$ Greece App no 14807/89 (ECtHR, 26 September 1995).

${ }^{160}$ Kriebaum (n 152) 223.

${ }^{161}$ Christoph Schreuer and Ursula Kriebaum, 'The Concept of Property in Human Rights Law and International Investment Law' in Stephan Breitenmoser, Bernhard Ehrenzeller, Walter Stoffel, Beatrice Wagner Pfeifer and Marco Sassoli (eds), Human Rights, Democracy and the Rule of Law (Nomos 2007) 743.
} 
liquidation, it may well be qualified as possession, ${ }^{162}$ but not under any other scenario. ${ }^{163}$ Put differently, only shareholders' property rights and not their financial interests are protected under the ECHR, a position the ECtHR borrowed from the Barcelona Traction reasoning. ${ }^{164}$

Applying this general rule to the Crimea scenario, both majority and minority shareholders cannot claim the consequential loss in the value of the shares ${ }^{165}$ resulting from mistreatment of the company, if the company can apply separately or through its liquidators. However, if the said mistreatment directly affects the businesses of the shareholder linked to the mistreated company's business, in this case the shareholder may be regarded as a victim. $^{166}$

Unlike in the human rights context, in the investment protection system an indirect expropriation without actual transfer or direct loss is still regarded as property taking, ${ }^{167}$ as it has an effect on the shareholders' possession. ${ }^{168}$ This, of course, depends on the wording of the particular treaty in question.

To compare the two dispute resolution mechanisms, nationality and legal personality of the individual applicant do not play a decisive role in the activation of the protection under the ECHR. However, individual shareholders, especially minority shareholders and those whose possession is limited to monetary interest, ${ }^{169}$ or those only affected indirectly ${ }^{170}$ may lack separate standing from that of the company's before the ECtHR. Thus, Ukrainian investors may arguably have more chances to protect their rights under the framework of ECHR vis-re the shareholders. Given the illegality of Russiatheannexation conduct, the illegality of follow-up conduct attributable to that state would be consistent from a systemic perspective and the principle of effective protection of individuals under a state jurisdiction. Thus, the human rights models of jurisdiction provide for a more adequate framework to ensure the protection of investors than the relatively unsettled investor-state models.

\footnotetext{
${ }^{162}$ Sovtransavto Holding $v$ Ukraine App no 48553/99 (ECtHR, 25 July 2002), para 9.

${ }^{163}$ Sarah C C Tishler, 'A New Approach to Shareholder Standing Before the European Court of Human Rights' (2015) 25(2) Duke J Comp \& Intl L 259.

${ }^{164}$ Case Concerning Barcelona Traction, Light and Power Limited (Belgium v Spain) (Judgment) [1970] ICJ Rep 3 [34]-[45] (Barcelona Traction case).

${ }^{165}$ Yarrow Plc and others $v$ United Kingdom App no 9266/81 (ECtHR, 28 January 1983), para 185; Renta 4 SVSA and others $v$ Russian Federation, SCC Arbitration No 24/2007, Award of 20 July 2012, paras 17, 22-4 (Renta 4).

${ }_{166}$ Agrotexim (n 159) paras 155-56.

${ }^{167}$ Waste Management (n 93).

${ }_{168}$ Paparinskis (n 24) 219.

${ }^{169}$ Siemens $A G v$ Argentine Republic, ICSID Case No ARB/02/8, Decision on Jurisdiction of 3 August 2004, para 91.

${ }^{170}$ CMS Gas Transmission Co v Argentine Republic, ICSID Case No ARB/01/8, Decision on Jurisdiction of 17 July 2003, para 48.
} 


\section{Admissibility under the ECHR: an analysis of the exhaustion of domestic remedies requirement}

Exhaustion of domestic remedies is generally required in a human rights regime but not in foreign investment frameworks. ${ }^{171}$ Neither the Russia-Ukraine BIT ${ }^{172}$ nor the ECT require an investor to make use of the domestic remedies before it can bring the dispute before an international tribunal.

The requirement of exhaustion of domestic remedies applies to both inter-state and individual cases as a preliminary condition for the examination of the case on merits. ${ }^{173}$ The exceptions to this rule include denial of access to remedies, prevention from their exhaustion, and lack of effectiveness or adequacy of available remedies. ${ }^{174}$ The exceptions apply provided that substantial ${ }^{175}$ evidence of these exceptions exists in relation to repetition, accumulation and official state tolerance of relevant human rights violations. ${ }^{176}$

The first concern in this regard is the effectiveness and will of the Russian domestic judiciary to deal with issues related to the property claims of Ukrainian investors. The second concern is related to whether the ECtHR would be open to waive the requirement of domestic litigation in the annexing country in light of its decision in Demopoulos and others $v$ Turkey. The Court held that where there is no direct correlation of the official recognition or the purported assumption of sovereignty of the annexing state over the annexed territory and the application of article 35 of ECHR, the exhaustion of domestic remedies requirement was not to be waived. ${ }^{177}$ The third concern regards the independence of the Russian judiciary, which is obliged to refer to the Russian Constitutional Court under article 125(4) of the Constitution ${ }^{178}$ when considering the application of ECtHR decisions under certain circumstances. ${ }^{179}$ According to the most recent 2017 ruling of the Russian Constitutional Court, ${ }^{180}$ the state is not under an obligation to comply with ECtHR judgments, ${ }^{181}$ where a

\footnotetext{
${ }^{171}$ Paparinskis (n 24) 231.

${ }^{172}$ Russia-Ukraine BIT (n 52) art 9.

${ }^{173}$ ECHR, art 35.

${ }^{174}$ Schabas (n 120) 764-65; Caraon and others $v$ United Kingdom App no 42184/05 (ECtHR, 16 March 2010).

${ }^{175}$ Georgia (n 125) paras 15, 32, 34.

${ }^{176}$ France, Norway, Denmark, Sweden and the Netherlands v Turkey App nos 9940-9944/82 (Commission decision, 6 December 1983).

${ }^{177}$ Demopoulos and others $v$ Turkey App nos 46113/99, 3843/02, 13751/02, 13466/03, 10200/04, 14163/04, 19993/04, 21819/04 (ECtHR, 1 March 2010), para 101.

${ }^{178}$ Constitution of the Russian Federation (adopted 12 December 1993, entered into force 25 December 1993) 237 Rossiiskaya Gazeta Newspaper 3 art 124(4).

${ }^{179}$ Maria Smirnova, 'Russian Constitutional Court Affirms Russian Constitution's Supremacy over ECtHR Decisions' EJIL:Talk! (15 July 2015) <www.ejiltalk.org/russian-constitutional-court-affirms-russianconstitutions-supremacy-over-ecthr-decisions/> accessed 21 August 2016.

${ }^{180}$ Constitutional Court of the Russian Federation, Judgment on the Compliance with a Ruling of the European Court of Human Rights of 19 January 2017513 Rossiiskaya Gazeta Newspaper 2.
} 
Strasbourg decision is deemed as incompatible with the Russian Constitution despite the finality and binding nature of ECtHR awards. ${ }^{182}$

Finally, exhaustion of domestic remedies prior to the recourse to ECtHR may preclude the applicant from triggering investment arbitration procedures under the fork-in-the-road clause included in some investment instruments ${ }^{183}$ provided that the 'triple identity' test is satisfied. As emphasised in Yukos v Russia, ${ }^{184}$ 'triple identity' concerns the same identity of parties, cause of action and object of the dispute.

\section{Available remedies}

Under the human rights regime, expropriation does not automatically lead to full compensation. In contrast, under the investment regime the duty to compensate is linked to expropriation and its lawfulness. In fact, 'prompt and effective' compensation is a constitutive element of the notion of lawful expropriation. Otherwise, the expropriation will be unlawful and a higher amount of compensation may be due. ${ }^{185}$ Further, the threshold for a finding of expropriation in the human rights regime is higher than under the investment treaty framework and should amount to 'total deprivation'. This excludes proportional and nondiscriminatory deprivation ${ }^{186}$ for public purposes. ${ }^{187}$

Thus, if the interference accords with public interests or does not impose a burden on the victim, a property owner may receive fair market value compensation. ${ }^{188}$ However, with protection of foreigners, the proportionality test threshold is raised under general principles of international law. ${ }^{189}$ Full compensation linked to the value of property taken exists only with regards to deprivation of property, whereas control of the enjoyment of possession will consequently bring the claimant just satisfaction. ${ }^{190}$

Finally, reparations awarded in investment proceedings and ECtHR proceedings are radically different. While in $O A O N K$ Yukos the ECtHR awarded EUR 1,866,104,634, ${ }^{191}$ an

\footnotetext{
${ }^{181}$ Yukos ECtHR (n 112).

182 Iryna Marchuk, 'Flexing Muscles (Yet Again): The Russian Constitutional Court's Defiance of the Authority of the ECtHR in the Yukos Case', EJIL:Talk! (13 February 2017) <www.ejiltalk.org/flexing-muscles-yet-againthe-russian-constitutional-courts-defiance-of-the-authority-of-the-ecthr-in-the-yukos-case/> accessed 15 February 2017; ECHR, art 46.

${ }^{183} \mathrm{ECT}$, art 26(3)(b)(i).

${ }^{184}$ Yukos PCA (n 101) paras 591-98.

${ }^{185}$ Dolzer and Schreuer (n 49) ch 13.

${ }^{186}$ Marckx v Belgium App no 6833/74 (ECtHR, 13 June 1979).

${ }^{187}$ Protocol I, art 1; Papamichalopoulos v Greece App no 14556/8923 (ECtHR, 24 June 1993); Sporrong and Lönnroth $v$ Sweden App nos 00007151/75 and 00007172/75 (ECtHR, 23 September 1982).

188 James and others $v$ United Kingdom App no 8793/7921 (ECtHR, 21 February 1986), para 54.

${ }^{189}$ Kriebaum (n 152).

190 ibid.

${ }^{191}$ Yukos ECtHR (n 112).
} 
arbitral tribunal awarded in Yukos Universal Limited USD 50,020,867,798 in damages plus EUR 156,476 for the arbitration costs and USD 2,214,277 for legal representation. ${ }^{192}$

Another issue which casts doubts on the effectiveness of the ECHR framework concerns enforceability. Concretely, the Constitutional Court of the Russian Federation has decided that the Federal Constitution has priority over ECtHR. ${ }^{193}$ However, the enforcement system of arbitral awards presents its own problems.

One example worth mentioning is the Yukos awards ${ }^{194}$ enforcement challenges. Yukos claimants have sought to enforce arbitral awards in jurisdictions where the Russian Federation assets can be found. Russia has never voluntarily complied with investment arbitration awards, so it is the process of enforcement that is crucial in ensuring the claimants' reparation. ${ }^{195}$

However, the process of enforcement of Yukos awards has thrown up its own host of challenges. Many awards have been set aside ${ }^{196}$ or their enforcement refused ${ }^{197}$ at the seat of arbitration on a number of grounds. For example, The Hague District Court set aside an award in favour of Yukos on the grounds that Russia had never ratified the ECT (on the basis of which the claim had been brought). This was surprising because the ECT contained a clause providing for the provisional application of the treaty upon signature alone. This experience of unsuccessful enforcement proceedings may present another hurdle in the ability to successfully hold Russia to account under the investment law system. ${ }^{198}$

To conclude, human rights and investment treaty frameworks are different worlds, 'but not apart'. ${ }^{199}$ Still, well-established jurisdictional flexibility, including extraterritorial

\footnotetext{
${ }^{192}$ Yukos PCA (n 101).

${ }^{193}$ Smirnova (n 179).

${ }^{194}$ The Russian Federation v Hulley Enterprises Limited, C/09/477160 / HA ZA 15-1; The Russian Federation $v$ Yukos Universal Limited, C/09/481619 / HA ZA 15-112; The Russian Federation v Veteran Petroleum Limited, C/09/477162/HA ZA 15-2 ('The Hague Court Judgments') <www.italaw.com/sites/default/files/casedocuments/italaw7258.pdf $>$ accessed 8 August 2016.

${ }^{195}$ Julien Fouret and Perre Daureu, 'Case Comment: Yukos Universal Limited (Isle of Man) v The Russian Federation - Enforcement of the Yukos Awards: A Second Noga Saga or a New Sedelmayer Fight?' (2015) 30 (2) ICSID Rev 336, 336.

196 'The Yukos Affair. Baiting the Bear' The Economist (London, 14 April 2016) $<$ www.economist.com/news/business/21696960-russia-trying-impede-enforcement-massive-damages-awardbaiting-bear> accessed 14 February 2017.

${ }^{197}$ Anastasia Choromidou, 'Investment Arbitration Award Enforcement - Yukos Saga Continues' (International Arbitration Attorney Network, 6 December 2016) <www.international-arbitration-attorney.com/investmentarbitration-award-enforcement/> accessed 21 June 2017.

${ }^{198}$ Daniella Strik, Georgios Fasfalis and Marc Krestin, 'Yukos Awards set Aside by The Hague District Court' Kluwer Arbitration Blog (27 April 2016) <www.kluwerarbitrationblog.com/2016/04/27/yukos-awards-set-asideby-the-hague-district-court/> accessed 26 July 2017.

${ }^{199}$ Bruno Simma and Dirk Pulkowski, 'Two Worlds, but Not Apart: International Investment Law and General International Law' in Mark Bungenberg, Jörn Griebel, Stephan Hobe and August Reinisch (eds), International Investment Law (Hart Publishing 2015) 361.
} 
protection and inclusive substantial protection granted to individuals regardless of nationality make ECtHR more feasible and accessible ${ }^{200}$ for the protection of Ukrainian investors in Crimea. At the same time, foreign investors with minority interests in Ukrainian companies will have better prospects of success in investment arbitration due to the existence of indirect and consequential losses standards.

\section{DIPLOMATIC PROTECTION OF FOREIGN INVESTORS IN CRIMEA}

Diplomatic protection can be reasonably described as an old and well-established mechanism of protection in international law. The ILC Draft Articles on Diplomatic Protection (DADP) were adopted following its subtraction from the Draft Articles on State Responsibility, where Garcia Amador had originally placed some provisions on the subject. ${ }^{201}$ The DADP define diplomatic protection in the following terms:

...[D]iplomatic protection consists of the invocation by a State, through diplomatic action or other means of peaceful settlement, of the responsibility of another State for an injury caused by an internationally wrongful act of that State to a natural or legal person that is a national of the former State with a view to the implementation of such responsibility. $^{202}$

As Crawford maintains, diplomatic protection serves an important purpose in international law, as it sets the international minimum standard of protection of persons and property. ${ }^{203}$ This is important because the protection of aliens embodies an important exception to the principle of sovereignty according to which what happens within a state's jurisdiction pertains exclusively to its internal affairs. ${ }^{204}$ That is not the case regarding aliens, as they are themselves interests of their state of nationality, thus making wrongs caused upon them following the international responsibility by the host state, a wrong caused upon the state of nationality itself. ${ }^{205}$

There are advantages and limitations vis-à-vis the usefulness of diplomatic protection as one of the means for protecting foreign investors in Crimea. However, issues such as the standard of protection will not be covered here, as it does not pose a fundamental question

\footnotetext{
${ }^{200}$ ECtHR's Public Relations Unit 'Your Application to the ECtHR: How to Apply and how Your Application is Processed' (Strasbourg 2012).

${ }^{201}$ ILC, 'Draft Articles on Diplomatic Protection with Commentaries' (1997-2006) UNGAOR Supp no 10 UN Doc A/61/10 (DADP).

202 ibid art 1.

${ }^{203}$ Brownlie (n 57) 607.

${ }^{204}$ ibid 605.

${ }^{205}$ ibid 607.
} 
given the factual circumstances serving as a vehicle for this analysis. ${ }^{206}$ Diplomatic protection will be analysed in the context of its advantages and limitations including nationality of the injured alien, exhaustion of domestic remedies and reparations.

\section{Advantages of diplomatic protection}

First, the definition of diplomatic protection regards as objects of protection both individuals and property. This is an advantage if one considers that, as studied before, the human rights law framework requires a great deal of argumentative gymnastics if the purpose is to protect a certain type of property.

Second, diplomatic protection encompasses judicial means of dispute settlement, but also a wide array of diplomatic means, therefore providing for flexible avenues non-existent in investor-state arbitration and human rights forums. Moreover, pursuance of this avenue does not preclude the use other forums including human rights courts or investment tribunals ${ }^{207}$ unless specifically provided. ${ }^{208}$

Finally, on the policy level, Russia would be interested in being open to diplomatic protection claims by third states because that may carry an implied recognition of its sovereignty claims over Crimea. ${ }^{209}$ That has been precisely its overall narrative since the conflict arose. However, states exercising diplomatic protection in a way which legitimises Russia's sovereignty claims would be in breach of the obligation 'to refrain from any action or dealing that might be interpreted as recognising any such altered status of the Autonomous Republic of Crimea'. ${ }^{210}$ That, in turn, carries its own policy and international relations implications which would determine in the long term whether any diplomatic protection action is undertaken by third states whose nationals have been affected by Russian sponsored action in Crimea.

\section{Limitations of diplomatic protection}

a) Exhaustion of domestic remedies

Customary international law $^{211}$ requires investors to exhaust all available domestic remedies, i.e. judicial and administrative remedies ${ }^{212}$ provided in the legal system of the state alleged to be responsible for causing the injury. ${ }^{213}$

\footnotetext{
206 ibid 614-16.

${ }^{207}$ DADP (n 201) art 15.

${ }^{208}$ ICSID Convention, art 27.

${ }^{209}$ Happ and Wuschka (n 13) 253.

${ }^{210}$ UNGA Res 68/262 (n 13); UNGA Res 2734 (XXV) (n 105).

${ }^{211}$ DADP (n 201) arts 14-15.

${ }^{212}$ Case Concerning Elettronica Sicula SpA (US v Italy) (Judgment) [1989] ICJ Rep 137 [59] (ELSI case).

${ }^{213}$ Brownlie (n 577) 472; Interhandel Case (Switzerland v United States of America) (Preliminary objections) [1959] ICJ Rep 6.
} 
In the specific circumstances of the Crimea scenario, exhaustion of domestic remedies raises a series of issues. Firstly, it is doubtful whether the Russian judicial system provides for effective remedies, particularly because serious concerns exist as to the independence of Russian courts when adjudicating politically sensitive issues. ${ }^{214}$ These considerations have been offered above and will not be restated here, but the issue is that there are grounds to suggest that the situation could surpass the abstract threshold of obvious futility, ${ }^{215}$ with complete absence of reasonable prospects of success. ${ }^{216}$ In those circumstances, the victim would not have to exhaust local remedies.

Secondly, as indicated in above concerning the ECtHR's stance in Demopoulos $v$ Turkey, ${ }^{217}$ the domestic remedies requirement may not be waived because of the hardships for an alien to exhaust them if the premise is that Russia acted extraterritorially and therefore the territorial jurisdiction ${ }^{218}$ of domestic courts is questionable. In any event, if Russia does not provide a reasonable possibility of effective redress, then this requirement may be waived. ${ }^{219}$

If the expectation is to obtain redress not from Russia but from Ukraine due to its failure to protect, aliens may alternatively seek the redress in the civil and commercial courts of Kyiv region in Ukraine due to the inability to deliver justice by the courts of Crimea in the temporarily occupied territories. ${ }^{220}$

According to the Law of Ukraine on Guaranteeing the Rights and Freedoms of Citizens and on the Legal Regime in the Temporarily Occupied Territory of Ukraine: '... [c]ompensation of damage caused to legal entities, citizens of Ukraine, foreigners and stateless persons as a result of the temporary occupation of Ukraine is fully vested in the Russian Federation as the country that performs the occupation'. ${ }^{221}$ Hence, in these circumstances remedies should be exhausted, provided that the Ukrainian legal system guarantees their effectiveness. Whether this allows for redress for wrongs attributable to Ukraine based on non-compliance with its duty to prevent at stages preceding the annexation is, however, doubtful.

\section{b) Nationality of the injured party}

\footnotetext{
${ }^{214}$ Smirnova (n 179).

${ }^{215}$ Claim of Finnish shipowners against Great Britain in respect of the use of certain Finnish vessels during the war (Finland v Great Britain) [1934] 3 RIAA 1479, 1498.

${ }^{216}$ DADP (n 201) art 15.

217 Demopoulos (n 160) para 101.

${ }^{218}$ Case of Certain Norwegian Loans (France v Norway) (Judgment) [1957] ICJ Rep 9 [39]-[40].

${ }^{219}$ DADP (n 201) art 15. See also The Panevezys-Saldutiskis Railway Case (Estonia v Lithuania) (Judgment) [1939] PCIJ Rep Series A/B No 76.

${ }^{220}$ On Guaranteeing the Rights and Freedoms of Citizens and on the Legal Regime in the Temporarily Occupied Territory of Ukraine, Law of Ukraine No 1237-VII of 6 May 2014 arts 3, 5, 12.

${ }^{221}$ ibid art 5.
} 
The nationality of an injured alien is crucial for the invocation of diplomatic protection. The rules on nationality in the diplomatic protection context are more restrictive vis-ricti regional human rights treaty rules discussed in the previous section. Judge Fitzmaurice reasoned as follows:

[..T]he 'bond to nationality' between the claimant State and the private party for whom the claim is brought must be in existence at the time when the acts complained of occurred, or it would not be possible for the claimant State to maintain that it had suffered a violation of international law 'in the person of its national' ${ }^{222}$

Therefore, the nationality of the injured person must be continuous from the date of injury to the date of the official presentation of the claim, and must have been obtained for reasons unrelated to the claim and in a manner not inconsistent with international law. ${ }^{223}$

Rules regarding nationality of corporate entities are more complex than those relating to individuals. Corporate nationality is determined by reference to the place of incorporation, ${ }^{224}$ must be genuine ${ }^{225}$ and continuous. ${ }^{226}$ For this purpose, control by nationals of another state, business activities in the state of incorporation and financial control ${ }^{227}$ are relevant.

Concerning shareholders, the practice is also uncertain. The state of nationality may protect direct rights of shareholders - multiple nationals jointly, ${ }^{228}$ or separately, if the greater link of the injured person to one state or another is established. ${ }^{229}$ There is no authority regarding the right of the state to protect investors other than shareholders, such as nominees and trustees. ${ }^{230}$ However, it is not directly prohibited as long as the link between the state and the injured person is genuine and continuous.

According to the principles established in Barcelona Traction, the state of the shareholder's nationality may exercise diplomatic protection if the company has ceased to exist in its place of incorporation ${ }^{231}$ or alternatively, where the state of incorporation was itself responsible for inflicting an injury on the company. ${ }^{232}$ In Case Concerning Elettronica

\footnotetext{
${ }^{222}$ Case Concerning Barcelona Traction, Light and Power Limited (Belgium v Spain) (Separate Opinion) [1970] ICJ Rep 3 [61] (Judge Sir Gerald Fitzmaurice) (emphasis added).

${ }^{223}$ DADP (n 201) arts 5, 10.

224 ibid art 9.

${ }^{225}$ Nottebohm case (Liechtenstein v Guatemala) (Second Phase Judgment) [1955] ICJ Rep 4 [70].

${ }^{226}$ Barcelona Traction case (n 164).

${ }^{227}$ DADP (n 201) art 9.

${ }^{228}$ Dallal $v$ The Islamic Republic of Iran, Bank Mellat [1983] 3 Iran-USCTR 10.

${ }^{229}$ Nottebohm case (n 225).

${ }^{230}$ DADP (n 201) art 11.

${ }^{231}$ Barcelona Traction case (n 164) [65]-[68].

232 ibid.
} 
Sicula SPA, the ICJ took a different approach, allowing the United States to represent the US shareholders of the existing company. ${ }^{233}$ Thus, the states of foreign shareholders' nationality may potentially exercise diplomatic protection against Ukraine as the state of incorporation.

Even when the nationality link is established and domestic remedies are exhausted, the state does not have an obligation to exercise diplomatic protection. Lord Phillips MR concluded: '[..i]t is clear that international law has not yet recognised that a state is under a duty to intervene by diplomatic or other means to protect a citizen who is suffering or [is being] threatened with injury in a foreign state'. ${ }^{234}$

However, as a recommended practice, i.e. not binding under customary law, article 19 of DADP suggests that due consideration be given to requests of diplomatic protection. ${ }^{235}$ National case law supports this approach in common law jurisdictions. ${ }^{236}$

\section{c) Reparations}

Since the injury in the diplomatic protection context is suffered by the state of nationality, then there is no obligation to transfer reparations to individuals directly wronged. ${ }^{237}$ However, article 19 of the DADP recommends that this be implemented as good practice. ${ }^{238}$

If investment treaty claims are assessed purely on the basis of the harm caused to the economic interests of the investor, damages suffered by an injured alien are never identical in kind with the state's injury. ${ }^{239}$

That reparations may be out of reach to the investor does not equate to there not being an incentive to pursue the diplomatic protection avenue. In some instances, cessation of the wrongful act ${ }^{240}$ would satisfy the investor's expectations, in others cessation may equate restitution. $^{241}$

In sum, injured aliens have a right to request their home state to exercise diplomatic protection on their behalf at any stage after the injury was suffered, or if the respondent state is not complying with an award or decision obtained in an investor-state arbitration proceeding or before a human rights court. Diplomatic protection may be considered as a safety net - an alternative venue for protection or an instance of last resort. In the absence of

\footnotetext{
${ }^{233}$ ELSI case (n 212).

${ }^{234} R$ (Abbasi) $v$ Secretary of State for Foreign and Commonwealth Affairs [2002] EWCA Civ 1598, [2003] UKHRR 76 [69] (Lord Phillips MR) (emphasis added).

${ }^{235}$ DADP (n 201) art 19.

${ }^{236} R$ (Abbasi) (n 234).

${ }^{237}$ La Grand Case (Germany v United States) (Judgment) [2001] ICJ Rep 466.

${ }^{238}$ DADP (n 201) art 19.

${ }^{239}$ Case Concerning the Factory at Chorzów (Germany v Poland) (Merits) [1928] PCIJ Rep Series A No 17.

${ }^{240}$ ILC, 'Draft Articles on Responsibility of States for Internationally Wrongful Acts with Commentaries' (1954 -2001) UNGAOR Supp no 10 UN Doc A/56/10 (ASRIWA) arts 29, 30.

241 ibid art 33. See also Paparinskis (n 24).
} 
investment or human rights frameworks diplomatic protection may be the only available international remedy.

Diplomatic protection on behalf of shareholders can be exercised against the state whose actions caused an international wrong, including the state of incorporation. Therefore, the states of shareholders' nationality may consider exercising diplomatic protection against Ukraine - the state of incorporation in the Crimea scenario. At the policy level, the state of shareholder's nationality may regard its diplomatic interest in strengthening ties with Russia as prevailing over its interest in the matter of its national. This may be a highly probable outcome because the position and interest of the state in a particular dispute is different from the investors' entrepreneurial focus and economic interests.

\section{E. CONCLUSIONS}

The annexation of Crimea illustrates a challenge to the international legal order in general and the regime of foreign investment protection in particular. Several investment claims brought under the framework of the Russia-Ukraine BIT by Ukrainian companies raised concerns about the prospects of investment treaty protection of Ukrainian and foreign nationals in the annexed territory of Crimea from the spectrum of available international venues for redress analysed in this article.

The objective difficulties which might impede the implementation of investment treaties in the circumstances of illegal use of force were solved in human rights case law and established in principles of extraterritorial protection. This article suggests that the human rights framework for the protection of individual and property rights extraterritorially and regardless of the injured alien's nationality make the ECtHR a more accessible venue for the protection of Ukrainian investors in Crimea than options available under investor-state arbitration. This, however, does not apply to shareholders. Their standing under the individual application process is limited to the protection of direct property rights. In this instance, the investor-state arbitration system offers a comprehensive case law on indirect investment protection under particular treaty instruments.

Furthermore, this article demonstrates that diplomatic protection provides an important opportunity, which may be the only one available in some instances, e.g. in cases of injured aliens whose home states do not have investment treaties with Russia in the Crimea scenario. However, diplomatic protection is discretional and limited by the political reluctance and pursuits of the state that may be different from the interests of the injured investor. Importantly, the Russian Federation is one of the five permanent members of the 
Security Council with veto-wielding power; therefore, some states of injured aliens' nationality will be more likely to exercise diplomatic protection against it than others, a decision that would hinge on 'realpolitik' concerns. ${ }^{242}$

In terms of practical considerations, both the human rights and diplomatic protection regimes provide for 'half a loaf' protection, which is in any event better than 'no bread'. In other words, just satisfaction or mere cessation of the wrongful act could provide sufficient (or at least acceptable) redress to investors who cannot gain access to remedies providing for standards akin to full reparation.

With respect to challenges, the annexation of Crimea will undoubtedly shape the potential treaty drafting practice that should appropriately answer the changing dynamics of international relations. Furthermore, since the territorial and the use of force questions in the Crimea scenario are unlikely to be fully resolved in the foreseeable future, ${ }^{243}$ they still will be conditioned by the domino consequences of pending and upcoming separate investment and human rights claims. Since the prohibition to legitimise Russia's illegal annexation does not preclude courts and tribunals to make their findings, these sectoral disputes may cause the illegality of the annexing state's conduct to be highlighted and possibly built up from a 'one case at a time' judicial approach. ${ }^{244}$

Human rights consequences, extraterritorial conduct, and huge losses for investors seem to be more easily talked about and dealt with because they do not require the international community to take a definite stand in the bigger political debate that would entail huge economic and legal consequences. The conclusion that follows is that investment and human rights claims connected with the annexation of Crimea set up the stage for bigger questions to be addressed in the future.

All articles published in the UCL Journal of Law and Jurisprudence are licensed under the Creative Commons Attribution License (CC-BY) 4.0 international license agreement and published open access, making them immediately and freely available to read and download. The CC-BY license agreement allows authors to retain copyright while allowing others to copy, distribute, and make some uses of the work. Further information regarding this can be found athttps://creativecommons.org/licenses/by/4.0/.

\footnotetext{
${ }^{242}$ Chittharanjan F Amerasinghe, Diplomatic Protection (OUP 2008) 189.

${ }^{243}$ Nuridzhanyan (n 13).

${ }^{244}$ Cass R Sunstein, Buy One Case at a Time: Judicial Minimalism on the Supreme Court (HUP 2001) 5.
} 